\title{
DOCUMENTS
}

\section{LATIN LISTS OF THE CANONICAL BOOKS.}

\section{AN UNPUBLISHED STICHOMETRICAL LIST FROM THE FREISINGEN MS OF CANONS.}

I. THE more important of the two lists which here follow-that printed on the left-hand page-is, so far as I know, now published for the first time. I derive it from Monac. lat. 6243 (olim Frising. 43), a MS of canons which belonged as early at any rate as the twelfth century to Freisingen, in the immediate neighbourhood of its present home at Munich. The collection of which this MS is the unique representative is described by Maassen in his Geschichte der Quellen, etc., pp. 476-486. He attributes the MS to the beginning of the ninth century; but seeing that there are a number of pieces added to the original collection, each in a different hand, and that of these additions one refers to the year 755 (Councll of Verneull), another to 756 (Council of Aschaim under Tassilo of Bavaria), and a third to c. 780785 (list of bishops of the Bavarian distructs), I do not see how the conclusion can be resisted that the original collection was made and written out not later than about the middle of the eighth century. These additions further prove that the MS was either written in Bavaria or brought there immediately after it was written.

The list of canonical books which I print begins on fol. $189 b$, and falls outside of what Dr. Maassen describes as die Sammlung der Handschrift von Freisingen which, according to him, commences on fol. I I with the words IN NOMINE DOMINI IESV CHRISTI INCIPIVNT CANONES and ends on fol. $189 a$ with the last of a series of decretals of Pope Gelasius. No doubt what falls between these two limits has a homogeneous character of its own, and may properly be distinguished from the rest when we come to the analysis of the component parts of the MS : but it does not correspond to the charactersstics, etther external or internal, of foll. I-10, 189-191, to distinguish them from the intervening 'collection' quite as sharply as Dr. Maassen does. Externally foll. I-I9I are all by the same scribe, and are all connected by a single system of notation of the quaternions; fresh hands begin, and the continuous signatures of the gatherings end, at fol. I92. Internal evidence tells a similar tale, for the documents contained on foll. $1-10$ belong all 
to the fourth century - the Law of Constantine against Arius, the Council of Damasus of A.D. $3^{82^{1}}$, and a very primitive version of some of the Canons of Nicaea and Sardica combined ${ }^{2}$. Thus our list of canonical books, which occupies from fol. $189 b$ to fol. I9I $b$ (being the last document in the hand of the original scribe), comes to us with good credentials and in good company.

Much weight cannot of course in itself be laid on the ascription of the list to St. Jerome: the names of the great Fathers, especially Jerome and Augustine, were almost the common property of scribes and copyists. Yet while I see nothing that tells necessarily for a later date than the first half of the fifth century-the mention of the term theotocos in line 45 of the Confession of Faith militates against a date earlier than circa A. D. $400-\mathrm{I}$ seem to see various indications that point to a date not much later than 400 . Some of these it is true may be satisfied by admitting an early date only for the Greek original from which the biblical list and stichometry professes to be drawn (iuxta grecum ostenditur); but this line of argument would do no more than transpose the centre of interest, for a fourth-century stichometry would be no less important in Greek than in Latin.

2. The second and subordinate list, which I reproduce here mainly for the purpose of comparison with the first, was printed from a Vatican MS (Reginae 199 , fol. $84 a$ : saec. xii) by F. Arevalo in his edition of the works of Sedulius (Rome, A. D. I 794), p. $429^{3}$. I derive my text, however, directly from a photograph which the Rev. K. Lake of Lincoln College was allowed, by the kindness of Father Ehrle, to take on my behalf. The list occurs in the middle of an imperfect work de Numeris - the rest of which is printed in Arevalo's edition of St. Isidore of Seville (vi1 397)-where it comes in rather oddly as an illustration of the number Two, some books being canonical, some on the other hand apocryphal. The non-canonical list, which I do not reproduce as it would be foreign to my present purpose, is that of the Gelasian Decree, and as Pope Gelasius is actually named in the preface to the list, it is clear that in its present form the list cannot be earlier than the sixth or seventh century. The only other source named in the preface is St. Athanasius, whose authority is therefore presumably invoked in connexion with the list of Biblical or canonical books: but it seems to me less likely that the Latin compiler had access to the list of St. Athanasius in the 39th Festal Epistle than to some later document like the Pseudo-Athanasian Synopsis.

1 Printed in J. T. S., July I900, p. 554.

2 Printed by Maassen, Geschuchte der Quellen, etc., pp. 921-923.

- See for this and for the Codex Sinaiticus Zahn's Geschichte des ntl. Kanons (II i $3^{8} 4$ ff.) - a vast repertory of information, of my indebtedness to which I make acknowledgement bere once for all. 


\section{$23^{8}$ THE JOURNAL OF THEOLOGICAL STUDIES}

\section{STICHOMETRICAL LIST FROM THE FREISINGEN MS}

(Monacensis lat. 6243 fol. 189 b).

Secundum Hieronimum ordo scripturarum necnon et uersuum quae habentur in canone ueteris testamenti quae de hebreo translata est et secundum ipsorum sententiam xxii libros compotati sunt iuxta ipsorum scilicet numerum litterarum hebraicarum, quarum ordo et numerus 5 uersuum iuxta grecum ostenditur.

$\begin{array}{lll}\text { Sic Genesis } & \text { habet uersus numero } & \overline{\mathrm{III}} \mathrm{CCCVIIII} \\ \text { Exodus } & \text { habet uersus numero } & \overline{\mathrm{III}} \mathrm{CCC} \\ \text { Leuiticum } & \text { habet uersus numero } & \overline{\mathrm{II}} \mathrm{DCC} \\ \text { Numeri } & \text { habet uersus numero } & \overline{\mathrm{III}} \mathrm{DXxxV} \\ \text { Deuteronomius } & \text { habet uersus numero } & \overline{\mathrm{III}} \mathrm{C} \\ \text { Iesu Naue } & \text { habet uersus numero } & \overline{\mathrm{I}} \mathrm{C} \\ \text { Iudicum } & \text { habet uersus numero } & \overline{\mathrm{II}} \mathrm{L} \\ \text { Ruth } & \text { habet uersus numero } & \mathrm{CCCXx}\end{array}$

hii libri viII habent uersus numero $\overline{\mathrm{XXI}} \mathrm{ccccx}$ III

I5 Regnorum sunt libri IIII sed secundum hebraeos computantur if ita liber primus habet uersus numero $\overline{\mathrm{D}}$
liber II
habet uersus numero
CCCCXLIIII

liber III

habet uersus numero

$\overline{\mathbf{I}} \mathrm{DC}$

facti sunt uersus numero

X XLIII

19. facti sunt scripsi : fs (et sic semper) F 
(Vaticanus Reginae 199 fol. 84 a).

Duobus sine dubio modis tota scriptura intellegenda est. primus itaque modus est intellegendi ut qui sunt libri qui scribendi legendi retınendi sunt ecclesia catholica intellegat. secundus autem modus est ut qui sunt libri qui nec legendi nec scribendi nec recipiendi sunt sciat.

Ordo itaque diuinorum librorum quos ecclesia catholica scribere 5 legere recipere debet secundum traditionem sanctorum uirorum et orthodoxorum patrum, hoc est Gelasii papae cum Lxx episcopis eruditissimis uris in sede apostolica urbis Romae, et secundum traditionem sancti Athanasii episcopi Alexandriae ciuitatis.

Hoc est uetus testamentum qui Thorath aebraice, Nomos grece, Lex ro latine appellatur, numero uersuum $\overline{\text { IIII }}$ cCcviIII secundus liber qui Helismoth hebraice, Exodus grece, Exitus latine uocatur, numero uersuum İī CCC

tercius liber qui Vaiethra aebraice dicitur et aput nos Leuiticus appellatur, numero uersuum $\overline{\text { II }}$ DII

quartus liber qui Viciedaber hebraice, Rithmos grece, Numerus latine uocatur, numero uersuum $\overline{\mathrm{III}} \mathrm{DXxx}$

quintus liber qui Abdabarim hebraice, Deutronomium grece, Secunda Lex latine, numero uersuum $\overline{\text { III }} \mathbf{c}$

hi sunt v libri Moysi qui aput grecos Pentatheocum appellantur, quod 20 latine sonat $\mathrm{v}$ libri : penta enim grece $\mathrm{v}$ latine dicitur, theocus autem grece liber latine intellegitur.

sextus itaque liber qui h uraice Iosuae Ben Nun, grece autem Sother Bar Nun, latine uero Saluator Filius Nun dicitur, numero uersuum $\bar{i}$ ccLXxxI

septimus autem liber qui aput hebreos Sopthim et apud latinos Iudicum uocatur, numero uersuum $\overline{\mathrm{II}}$ CLI

hi sunt vil libri legis quos greci Eptatheochos appellant (epta enim grece vir latıne, theocos grece libri uel libros latine) quos latini corruptae et strictae Eptaticum uocant.

Post hos viI libros III libri Regum secuntur, qui aput hebreos appellantur duo libri Samuhel et duo secundi Malachim; ex nomine udicis eorum Samuhel duos libros primos Regum appellauerunt et secundum proprietatem linguae eorum duos alios libros Malachim uocauerunt : Samuhel Precium De1 interpretatur, Malachim Regum 35 latine dicitur:

primus ergo Regum liber numero uersuum $\overline{\mathrm{II}} \mathrm{D}$ secundus tercius uero quartus uero numero uersuum CCCCXLIII numero uersuum $\overline{\mathrm{II}} \mathbf{D}$ numero uersuum $\overline{\mathrm{II}} \mathrm{DC}$ 


\section{LIST OF THE FREISINGEN MS (continued)}

20 Paralypomenon sunt libri il et secundum hebreos computatur unus : ita

liber I habet uersus numero $\overline{\mathbf{I}} \operatorname{CcLxx}$

liber $\mathrm{II}$ habet uersus numero $\overline{\mathrm{in}}$

facti sunt uersi numero

25 Esdrae libri II et aput hebreos computatur unus :

$\begin{array}{lll}\text { liber I } & \text { habet uersus numero } & \text { M CCCX } \\ \text { liber II } & \text { habet uersus numero } & \text { M DCCC }\end{array}$

${ }_{h}$ facti sunt uersus numero

30 Ster liber I habet uersus numero DCCL

Macchabeorum sunt libri inI, secundum hebraeos computantur II :

$\begin{array}{lll}\text { liber I } & \text { habet uersus numero } & \overline{\mathrm{I}} \mathrm{DXxV} \\ \text { liber II } & \text { habet uersus numero } & \overline{\mathrm{I}} \mathrm{DCCCL} \\ \text { liber III } & \text { habet uersus numero } & \overline{\mathrm{I}} \mathrm{DCCL} \\ \text { liber III } & \text { habet uersus numero } & \mathrm{M} \mathrm{CCX}\end{array}$

facti sunt uersus numero

Psalmorum liber I habet uersus numero $\quad \overline{\mathbf{v}} \mathbf{x}$

$\overline{\mathrm{v}} \operatorname{ccLxx}$

Salomonis libri $\mathrm{v}$ : ita

40 prouerbia habet uersus numero M DCCCL

sapientia Sirac habet uersus numero $\overline{\mathrm{II}} \mathrm{DCV}$

canticum canticorum habet uersus numero CCLXXX

ecclesiastes habet uersus numero DCCCL

sapientia Salomonis habet uersus numero M C

45 facti sunt uersus numero

Iob liber I

habet uersus numero M DCCC

secundum autem hebreos amplius habet uersus numero

ergo sunt omnes uersus

M

$\overline{\text { III }} \mathrm{C}$

$\overline{\text { VIIII }} \operatorname{CCC} \mathrm{XXv}$

$\overline{\mathrm{VI}} \mathbf{D C C C L X X}$

50 Prophetae numero XvI

Esalae liber I habet uersus numero $\overline{\text { III }}$ DCCC

Hieremiae cum Baruc et Lamentationem cum Epistula habet uersus numero $\overline{\mathrm{III}} \mathrm{D} \mathrm{DCCX}$

Ezechihel liber I habet uersus numero inI

55 Danihel liber habet uersus numero $\mathrm{M}$ DCCXX

Libri xII Prophetarum habent uersus numero

$\overline{\text { III DCCC }}$

facti sunt uersi numero

$\overline{\mathrm{XVII}} \mathrm{L}$

53. habet uersus scripsi: lib v (sc librı v) $f$ 


\section{LIST OF THE MS OF F. AREVALO (continued)}

Nomina itaque librorum qui post istos xI libros secuntur, haec sunt :

Dabreiamin ebraice, Paralippenon grece, Pretermissorum uel Verba dierum latine; qui diuiditur in duos libros:

primus secundus

numero uersuum $\overline{\mathrm{II}} \operatorname{ccLxx}$ numero uersuum $\overline{\text { III }}$

Hesdrae libri duo sunt : primus secundus numero uersuum $\bar{i}$ cCXL numero i DCCC

Psalmorum liber qui Nabla hebraice grece Organum latine dicitur, numero uersuum vic

Salomonis libri tres :

primus Masloth ebraice, Parabolae grece, Prouerbia latine dicitur, numero uersuum $\overline{\mathbf{I}}$ DCCLX

secundus qui Coeleth hebraice, Aecclesiastes grece, Contionator latine uocatur, numero uersuum $\overline{\mathbf{I}} \mathrm{DCCXL}$ tercius qui Sirasirim dicttur, latine autem Canticum Canticorum 55 uocatur, numero uersuum CCLXXX Sapientia quae dicitur Salomonis Sapientia Hiesu Filii Sirach

Liber Iob numero uersuum $\bar{I} \mathrm{LXX}$ numero uersuum $\overline{\mathrm{I}} \mathrm{DCCC}$ numero uersuum $\bar{i} \mathrm{DCC}$ si autem cum asteriscis $\overline{\mathrm{II}} \mathrm{DCC}$

Liber Tobi qui inter agiografa ponitur, numero uersuum $\overline{\mathbf{i}}$

Prophetae maiores IIII sunt, quorum libri nominantur nominibus eorum :

Esaias hebraice, Salus Domini latine dicitur, numero uersuum DCCCXXX

Hieremias hebraice, Excelsus Domini latine uocatur, numero uersuum $\overline{\text { III }}$ DCCCX

Ezechihel hebraice, Fortitudo Domini latine nominatur, numero uersuum $\overline{\mathrm{IIII}}$

Danihel hebraice, Iudicium Domini latine appellatur, numero uersuum î $\mathbf{D x x}$

Baruch hebraice id est xII Prophetarum liber unus, numero uersuum $\overline{\mathrm{III}} \mathrm{DCCC}$

Prophetarum omnium libri simul cum capitulis suis

Hester libri duo: primus secundus

Machabeorum libri IIII sunt :

primus secundus tercius quartus VOL. II. numero uersuum $\overline{\mathbf{X V I I I I}}$ CLXXV numero uersuum DCCL numero uersuum $\overline{\mathbf{I I}}$

numero uersuum DXXV numero uersuum $\mathrm{DCCC}$ numero uersuum DCr 80 numero uersuum $\mathbf{i}$ cc 
LIST OF THE FREISINGEN MS (continued)

ITEM NOVI TESTAMENTI

6o Euangeliorum libri IIII

secundum Mattheum liber habet uersus

numero

II DXX

secundum Marcum liber habet uersus

numero $\quad M$ DCC

65 secundum Luca liber habet uersus numero II DCCCL secundum Iohannem liber habet uersus numero

$\overline{\mathrm{II}} \operatorname{cccx}$

facti sunt uersus numero

Actus apostolorum quos disscripsit Lucas

7o euangelista liber habet uersus numero

III DCCC

Epistulae apostolorum canonicae

epistula Iocobi I habet uersus numero $\mathrm{ccc}$

epistula Petri habet uersus numero $\mathrm{CCC}$

75

item epistula Petri

5 secunda habet uersus numero cc

epistula Iohannis

prima habet uersus numero $\operatorname{ccLx}$

eiusdem secunda habet uersus numero LV

cuius supra III habet uersus numero Lxviri

80 epistula Iudae zelotes habet uersus numero LVI

facti sunt

M CCXL

Epistulae Pauli apostoli numero XIIII

ad Romanos habet uersus numero DCCCL

ad Corinthios I habet uersus numero DCCCXLII

$8_{5}$ ad Corinthios II habet uersus numero DCCXII

ad Galatas habet uersus numero cccxil

ad Ephesios habet uersus numero ccccxir

ad Philippenses habet uersus numero ccc

ad Thesalloni-

90

censes II habet uersus numero

$\operatorname{ccLxxx}$

cX

ad Colosienses habet uersus numero

$\begin{array}{lll}\text { ad Timotheum I habet uersus numero } & \text { xcvil } \\ \text { ad Filimonem } & \text { habet uersus numero } & \text { xLvirII }\end{array}$

ad Hebraeos habet uersus numero DCCL

CXIIII

95 facti sunt uersus numero

$\overline{\text { VIIII }} \operatorname{CCCLX}$

Apocalipsis Iohannis

apostoli habet uersus numero $\mathrm{M}$ CCCC

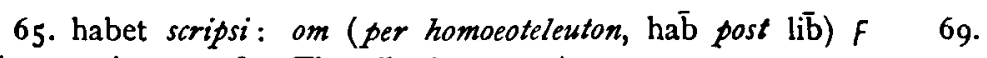
dis*scripsit $F \quad 89$. Thesollonicenses $F^{*}$ 
LIST OF THE MS OF F. AREVALO (continued)

Iudith liber numero uersuum $\overline{\mathbf{i}} \mathrm{DCCC}$

Veteris testamenti libri simul numero uersuum $\overline{\mathbf{L X X I I}}$ CCCXLVIII

Noui testamenti libri hi sunt.

III euangelia qui ex magistrorum nomine sunt nominati :

Matheus hebraice, Donatus latine dicitur, numero uersuum $\overline{\mathrm{II}} \mathrm{DC}$

Marcus Excelsus interpretatur, numero uersuum $\overline{\mathbf{1}}$ DCC

Lucas iste Consurgens interpretatur, numero uersuum $\overline{\mathrm{II}} \mathrm{DCCC}$

Iohannes Gratia Dei interpretatur, numero uersuum $\overline{\mathbf{I I}} \mathbf{~ C C C}$

Actus apostolorum

numero uersuum $\overline{\mathrm{II}} \mathrm{DCCC}$

Epistulae apostolorum canonicae vil, numero uersuum $\operatorname{ccxx}$

Epistulae Pauli apostoli xıII, numero uersuum $\overline{\mathbf{v}}$ cr

Apocalipsis Iohannis apostoli, quae interpretatur Reuelatio, numero uersuum $\overline{\mathrm{I}} \mathrm{DCCCL}$

Libri simul noui testamenti numero uersuum $\overline{\mathbf{x}} \mathbf{x} \operatorname{ccc} x \mathbf{x}$

Vtriusque testamenti simul libri numero uersuum $\overline{\mathrm{CCII}}$ DCLXVIII

[What follows in the MS of Arevalo, namely the Gelasian list of non-canonical books, is unaccompanied by a stichometry.] 


\section{LIST AND CREED OF THE FREISINGEN MS (continued)}

Facti sunt omnes uersus ueteris testamenti (exceptis $\mathrm{M}$ uersibus Iob, qui in hebraeo amplius sunt, quorum est signum astheriscus adnotatus 100 ad capita ipsorum) numero $\overline{\mathbf{L X X V I I I}}$ DCCCC $111 \mathrm{I}$ : item noui testamenti facti sunt numero $\overline{\mathrm{XVIIII}}$ DCCCC XIIII: ac sic omnes in unum ueteris et noui testamenti facti sunt uersus numero $\overline{\text { XCVIIII }}$ DCcC XXvir.

Additis ergo duobus libris Regnorum in numero xxIIorum ueteris testamenti, ipsum est mysterium quod sancta catholica ueneratur ecclesia, 105 in consecrationem ponens etiam Xxilı seniores. quattuor autem animalia secundum mysterium et spiritalem intellegentiam quattuor sunt euangelistae.

Ita MatThevs in typo hominis, quia in capite libri dixit: CHRISTI avtem Generatio sic erat et reliqua. Marcvs in typo leonis, quia uoce magna fremens a Iohanne baptista qui erat tunc in deserto sumpsit exordıum. Lvcas in typo uituli, quia praemissa breuiter praefatione ad

5 Theofilum a sacerdotio et hostia coepit. IoHANNIs in typo aquilae, mox mysticae ad caelestia conuolauit, quippe qui in pectus Domini ut mysterium agnosceret recubuerat, et uerae Boanirgis (quod est interpretatum Tonitrui filius) exclamauit: IN PRINCIPIO ERAT VERBVM ET VERBVM ERAT APVT DEVM ET DEVS ERAT VERBVM: HOC ERAT IN PRINCIPIO

Io APVT DEVM. erubescant et confundantur qui dicunt de filio dei Erat quando non erat, cum Iohannis dicat: ERAT, ERAT, ERAT. si erat, immo quia manifeste erat, hii non erunt qui in ipso neque sunt, qui persistentes dicunt fuisse aliquando solitarium patrem cum deus filius non erat: nos autem catholici dicimus et credimus Erat in patre semper et uerae

15 erat et numquam fuit quando non erat. nam et anathematezamus qui dicunt Non erat, quoniam de illo dicunt Antequam crearetur non erat, et eum tamquam creaturam in animae suae perniciae factum designant. ipse est ante omnia initia et ante omnia secula dei uirtus et dei sapientia, sine omne omnino intio inenarrabliter a patre non creatus sed genitus, so sine quo deus pater numquam solus erat. nam quis nisi insanus audeat uel cogitare uel dicere deum patrem sine uirtute et sine sapientia antequam eum inconparabiliter et inaestimabiliter genuerit fuisse, cum quando de filio rectae dicitur et rectae sentitur secundum ipsuus domini et saluatoris nostri adtestationem: EGO IN PATRE ET PATER IN ME,

IoI. In unus $F^{*}$

$\begin{array}{llll}\text { I. Matt. } \mathrm{i} 8 \mathrm{8} 8 \text { Jo. } \mathrm{i} \text { I, } 2 & \text { 18. I Cor. } \mathrm{i} 24 & \text { 24. Jo. xiv Io }\end{array}$

9. deus scripsi: di $F$ (cf. Old Latin Biblical Texts, No. II : Portions of the Gospel according to St. Mark and St. Matthew from the Bobbio MS $k$, p. clvii) II. non : om $F^{*}$ 16. 1llo scripsi: illi $F$ I7. designunt $F^{*}$ 18. uirtus scripsi: uirtute $F$ 


\section{CREED OF THE FREISINGEN MS (continued)}

EGO ET PATER VNVM SVMVS, et sicut omnis catholica confitetur ecclesia: 25 OMNIA PER IPSVM FACTA SVNT ET SINE IPSO FACTVM EST NIHIL. nam ipse dominus noster Iesus Christus filius dei deus uerbum dei uirtus et dei sapientia secundum donum gratiae suae loquitur in Paulo, et Paulus plenus gratia auxiliante sibi domino loquitur ecclesiae dicens : QVONIAM EX IPSO ET PER IPSVM ET IN IPSO OMNIA, IPSI GLORIA IN 30 SECVLA SECVLORUM. quod autem superius dixit dominus noster Iesus Christus : EgO ET PATER vNVM SvMvS, catholicus sensus ita hic eum dixisse intellegit VNVM propter unitatem patris et spıritus sancti qui non minor patri filioque est, svmvs propter personarum diuersitatem atque distinctionem: quia qui pater est neque filius neque spiritus sanctus est, 35 et qui filius est neque pater est neque spiritus sanctus est, et qui spiritus sanctus est neque pater neque filius est. sed est pater ingenitus, filius genitus, paraclitus spiritus sanctus non genitus sed procedens a patre. qualiter autem filius a patre sit genitus, nulla hoc debet mens catholica uel conscientia cogitare propter prophetiam quae dicit: GENERATIONEM $4^{\circ}$ AVTEM EIVS QVIS ENARRAVIT? est ergo pater ingenitus : filius genitus, non creatus neque factus, sed nobis ex tempore natus de spiritu sancto et Maria semper uirgine, propter quod non erubescimus neque pertimescimus immo audaciter confitemur et dicimus beatam Mariam uirginem theotocon: spiritus sanctus non genitus, procedens de ore 45 patris est. itaque trinitas haec est unita inconparabiliter atque inconprehensıbiliter, unius substantiae atque aeternitatis sıue diuinitatis. pater est de quo dicit filius ego a PATRE ExIvi ET A DEO VENI IN HOC MVNDo. filius est de quo uox patris est HIC EST FILIVS MEVS DILECTVS IN QVO MIHI BENE COMPLACVI, HVNC AVDITE, spiritus sanctus est 50 de quo dixit filius Nisi ABIERo AD PATREM NON VENIET AD vOS PARACLYTVS. tres ergo personas nos omnes catholici nominibus atque personis distınctas, id est patrem et filium et spiritum sanctum, unius substantiae atque diuinitatis confitemur et credimus : cuius nos gratia et adiutorio et in hoc et in futuro saeculo cupimus custodırı. memorati 55 ergo heretici de spiritu sancto, qui patri filıoque coaeternos et coaequalis est, non dubitant uana praesumptione detrahere et blasphemantes dicere : Posteaquam filius a patre creatus est, hanc esse primam filii creaturam, quia spiritum sanctum ipse sine patre creauerit. sed quoniam dementia
25. Jo. $\times 30$
26. Jo. i 3
30. Rom. xi 36
32. Jo. $x 30$
40. Is. liii 8
48. Jo. xvi 28
49. Matt. xvii 5
51. Jo. Xv1 7

27. nam: + et $F^{*}$ 30. ipso: ipse $F^{*}$ 56. coaeternus $F^{2}$
28. dei : sapientia primis curis scribere uoluit $f$ 42. ex tempore natus $F^{2}$ : ex*templo renatus $F^{*}$ et scripsi: est $F \quad 57$. praesumpitione $F^{*}$ ? 


\section{CREED OF THE FREISINGEN MS (continued)}

60 eorum non tam rideri quam a catholicis doleri potius debet, ut de non intellectis non intellecta confirment nolintque doceri sed AMANT PRIMOS DISCVBITOS IN CENAM ET SALVTATIONES IN FORO et IN CATHEDRA PESTILENTIAE resident: si conuersi errorem suum non reputauerint, sancta eos catholica et apostolica similiter anathematizat ecclesia.

EXPLICIT FIDES HIERONIMI

OMNIS LABOR FINEM HABET: PRAEMIVM EIVS NON HABET FINEM : ORA PRO ME PECCATORE SI HABEAS DEVM PROTECTOREM
61. Matt. xxiii 6
62. Ps. i I
61. intellectis $F^{2}$ : intellectus $F^{*}$
64. apostoli $F$

The principal point of contact between these two lists is their possession of what is certainly in the main, though with considerable differences in detail, a common stichometry. And this stichometry is quite independent of anything (so far as I know) that is elsewhere known in I atin. It presents points of contact with the well-known stichometry of the ninth-century Patriarch of Constantinople, Nicephorus; but stıll closer parallels are to be found in an eleventh or twelfth century Greek MS in the Barberın Library (Barb. iii $\left.3^{6}\right)^{1}$-the data of which I borıow from E. Klostermann's Analecta: I owe the reference to Dr. Swete's Introduction to the Old Testament in Greek, p. 349-and, for the Paulıne Epistles, in the Codex Sinaiticus. Since these figures in $\$$ are, according to Tischendorf, by a contemporary hand, we are taken back at once for this portion of the stichometry to the fourth century. And since in the Freisingen and in the Barberini MSS the Pauline stichometry is not 1solated but is according to all appearance an integral part of a complete stichometry of the Bible, the presumption is strong that the rest of the stichometry is of the same antiquity. At the same time I think it possible that the deutero-canonical books, or some of them, were not included in the original arrangement, since the amount of disagreement between the figures in our different authorities is considerably greater here than elsewhere. Apart from these cases it would not be difficult, from the comparative table which I give on pp. $248-25 \mathrm{I}$, to restore the original list with some measure of certainty. For this purpose the

1 This MS belonged originally to the library of the great monastery of S. Marna del Patire at Rossano, which was founded in the first years of the twelfth century (Batiffol, L'Abbaye de Rossano, p. 66). Its earliest MSS were probably brought from Constantinople. 
leading authorities would be the Freisingen and the Barberini MSS . Nicephorus' list represents either a somewhat advanced stage of corruption or a conflation with divergent systems. The figures thus restored would have a good claim to rank as the earliest known stichometry.

One feature of the two Latin lists-which reappears to some extent in the account of the Barberini MS, and perhaps would reappear more fully with fuller information-seems to me to confirm very strongly what I have conjectured of the high antiquity of the stichometry; and that is the note of the difference in length between the Septuagint and the Hebrew Job. The Freisingen MS tells us that 1000 extra verses (i. e. orixoc) were present in the Hebrew [and absent therefore from the Greek], which are marked [in the amplified editions of the Greek, where the missing verses were supplied] by an asterisk at their head. We have here of course a description of the Hexaplar MSS in which Origen supplied out of Theodotion the verses missing in the LXX. Similar knowledge of the Hebrew Old Testament is again evinced by the Freisingen list in the data of the various books which the Greeks counted as two, the Hebrew as one ${ }^{1}$; but this information is less important, for it is common to the biblical lists of Cyril of Jerusalem, of Athanasius, and of Rufinus.

If one were to hazard a conjecture as to the time and place at which this stichometry originated, the concurrent indications of its partial presence in $N$ and of its relation to MSS of the Hexapla might seem to point to Caesarea and to the library of Pamphilus. Were that so, the name of St. Jerome at the head of the Latin form of the stichometry might not be so purely imaginary as at first sight one would have been tempted to suppose.

With regard to the order and names of the Books of the two Testaments contained in the Freisingen list, I must content myself here with a few fragmentary notes. Of the deutero-canonical books Tobit and Judith are absent altogether; on the other hand four books of Maccabees (as in Arevalo's list) are enumerated, and are incorporated in this MS on a position of complete equality with the other historical books, the Octateuch being followed by Kings, Chronicles, Ezra, Esther and Maccabees; these by the poetical books, Psalms, Solomon and Job; and these by the sixteen Prophets. In the New Testament I notice the epithet 'canonical' for the Catholic Epistles, which our list shares with the Council of Damasus (J.T.S. i 559) and with the MS of Arevalo; and the title 'Zelotes' applied to St. Jude, which again is common with the Damasine list. The phrase 'Actus apostolorum quos descripsit Lucas ' recurs in Rufinus.

'The statement, however, that the four books of Maccabees rank as two in Hebrew is perhaps a corruption or an interpolation. I do not know of any parallel. 


\section{Old Testament Stichometries.}

Genesis
Exodus
Leviticus
Numbers
Deuteron
Joshua
Judges
Ruth

Octateuch

I Kings

2 Kings

3 Kings

4 Kings

4 B. of Kings

I Chronicles

2 Chronicles

2 B. of Chronicles

I Ezra

2 Ezra

2 B. of Ezra

Psalms

Books of Solomon :

Proverbs

Ecclesiastes

Canticles

Wisdom

Sirach

5 B. of Solomon cod. Frising.

4309

3300

2700

3535

3100

2100

2050

320

$$
500
$$

444

om.

2600

2600
2270
3000

I3ro

1800

No doubt we ought to read $\overline{\text { In }}$ Dcc for $\overline{\text { in }} \mathrm{pI}$

- By substituting I for $\mathrm{C}$ we get $\overline{\mathrm{n}} \operatorname{cLx\times x}$ (2181).

- This total tallies with the sum of the eight separate figures.

- This number is given by Klostermann, p. 45 ; Dr. Swete's 2600 (p. 350) is epparently a slip of the pen.

5 This total shows that we must read for the four separate books 2500,2443 , $2500,2600$.

- Probably we should read 1300 (with Barb. iii 36) for I Ezra in order to make this total correct.

"We must clearly read $\overline{\mathbf{v}} \mathrm{c}$ for $\overline{\mathbf{v}} \mathrm{x}$.

- If any common origin is to account for these four variations it must be $175^{\circ}$.

- Probably the two Latin authorities had 850 , and the two Greek $75^{\circ}$.

10 I suspect that 2800 should be read in all four authorities.

11 If the five separate books should read $175^{\circ}$ (for 1850 ). 850, 280, I100, 2800 (for 2605), the total would become 6780, $\bar{v}$ DCCLXXXX (cod. vin DCCCLXX). 
OLD TESTAMENT STICHOMETRIES (continued)

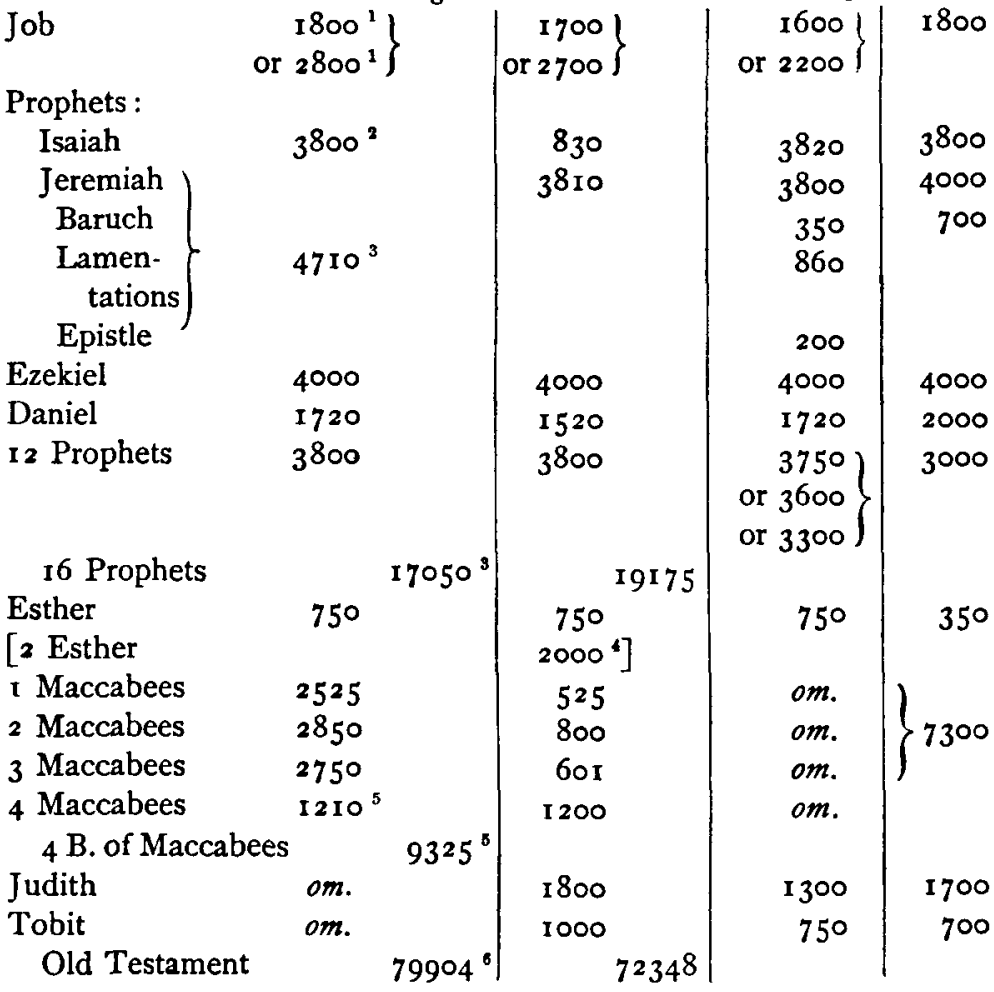

1 These figures for the LXX and Hebrew Job appear to be the best.

' In spite of the agreement with Nicephorus, we ought probably to read $3^{820}$ here with cod. Barb. : see next note.

If we read 3820 for Isalah, and 3710 instead of 47 10 for Jeremiah, the total for the Prophets will come right, 17050 .

- I suspect the explanation of the unintelligible Second Book of Esther with 2000 verses to be that the 2000 was intended to apply to all the first three books of the Maccabees, and somehow got separated from them and made into a substantive book.

- The total of the four books suggests that we should for 4 Maccabees read 1200 with cod. Arevali.

- Excluding (we are definitely told) the 1000 verses which the Hebrew has beyond the LXX. But the total of the separate figures (even as I have amended them) comes to 80722 , or 818 more than this. 


\section{New Testament Stichometries.}

\begin{tabular}{|c|c|c|c|c|c|}
\hline & cod. Frising. & cod. Arev. & $\begin{array}{l}\text { Barb. } \\
\text { iii } 36\end{array}$ & $\begin{array}{l}\text { Nice- } \\
\text { phorus }\end{array}$ & \\
\hline Matthew & 2520 & 2600 & 2600 & 2500 & \\
\hline Mark & 1700 & 1700 & I 700 & 2000 & \\
\hline Luke & 2850 & 2800 & 2800 & 2600 & \\
\hline John & $2310^{1}$ & 2300 & 2300 & 2300 & \\
\hline 4 Gospels & $9360^{1}$ & & & & \\
\hline Acts & $3^{8} 800^{2}$ & 2800 & 2800 & 2800 & \\
\hline \multicolumn{6}{|c|}{ 'Canonical' Epp. : } \\
\hline James & 300 & & 300 & & \\
\hline I Peter & 300 & & 300 & & \\
\hline 2 Peter & 200 & & 200 & & \\
\hline I John & 260 & & 260 & & \\
\hline 2 John & 55 & & $5^{6}$ & & \\
\hline 3 John & 69 & & $3^{\circ}$ & & \\
\hline Jude & $5^{6}$ & & 69 & & \\
\hline 7 Epistles & $1240^{3}$ & $220^{3}$ & I 200 & 1300 & \\
\hline Pauline Epp.: & & & & & $\begin{array}{l}\text { cod. Sinal- } \\
\text { ticus }(\boldsymbol{N})\end{array}$ \\
\hline Romans & $85^{\circ}$ & & 950 & & \\
\hline I Cor. & 842 & & 842 & & \\
\hline 2 Cor. & 712 & & 712 & & 612 \\
\hline Galatians & 312 & & 312 & & 312 \\
\hline Ephesians & 412 & & 312 & & 312 \\
\hline Philippians & 300 & & 200 & & 200 \\
\hline Colossians & IIO & & 300 & & 300 \\
\hline I Thess. & $o m$. & & 220 & & $o m$. \\
\hline 2 Thess. & 280 & & 180 & & 180 \\
\hline I Timothy & $97^{\prime}$ & & 236 & & 250 \\
\hline 2 Timothy & $o m$. & & 160 & & 180 \\
\hline Titus & $o m$. & & $o m$. & & 96 \\
\hline Philemon & 49 & & $o m$. & & $o m$. \\
\hline
\end{tabular}

1 Probably the last cypher ( $x$ ) of the sum for St. John should be transferred to the total : $2520+1700+2850+2300=9370$. But the figures for St. Matthew and St. Luke disagree with codd. Arevali and Barb.

${ }^{2}$ No doubt this should be 2800 , with all our other authorities : the change is confirmed by the cyphers given for the complete New Testament.

3 This total agrees with the sum of the seven separate figures. In cod. Arevalı we should certainly read $I 220$ ( $\bar{I} \operatorname{ccxx}$ ) for 220 . The sum of the seven separate figures in cod. Barb. - the first four tally exactly with the Fressingen list-comes to 1215 instead of 1200 . The most satisfactory solution would be to transpose the figures for 3 John and Jude in cod. Fris., giving 56 to 3 John and 69 (with cod. Barb.) to Jude. Possibly 3 John was absent from the original stichometry.

- This would appear to be really the figure for Titus; see the figures in $k$. 


\section{NEW TESTAMENT STICHOMETRIES (continued)}

\begin{tabular}{|c|c|c|c|c|c|}
\hline & cod. Frising. & cod. Arev. & $\begin{array}{l}\text { Barb. } \\
\text { in } 3^{6}\end{array}$ & $\begin{array}{l}\text { Nice- } \\
\text { phorus }\end{array}$ & $\begin{array}{l}\text { cod. Sina- } \\
\text { ticus (*) }\end{array}$ \\
\hline Hebrews & $75^{\circ}$ & & $750^{1}$ & & $75^{\circ}$ \\
\hline I 4 Epistles & I $14^{2}$ & 5101 & & 5300 & \\
\hline Apocalypse & 1400 & $1850^{3}$ & $o m$. & 1400 & \\
\hline Total : & & & & & \\
\hline $\begin{array}{l}\text { New Testament } \\
\text { Biblical }\end{array}$ & $\begin{array}{l}19914 \\
99828\end{array}$ & $\begin{array}{l}20320^{3} \\
92668^{3}\end{array}$ & & & \\
\hline
\end{tabular}

But the Freisingen MS does not contain only a list of the canonical books, but an anti-Arian profession of fatth, the transition to which is formed by an application of the Apocalyptic imagery of the 24 elders to the Books of the Old Testament-compare with this Mommsen's Cheltenham List-and of the four Living Creatures to the Evangelists. The opening words of the Gospel of St. John plunge the writer at once into the middle of the controversy with Aruus.

For the combination of the canon of scripture with a statement of (scriptural) doctrine some sort of illustration may be found in the Damasine Decree; but a much closer parallel is offered in a document to which my attention has been drawn by Kunstle, Eine Bibliothek der Symbole (Mainz, A. D. 1900), pp. 24, 121, 178. Kunstle's 'Library of Creeds' is a collection of doctrinal statements, mostly directed against Arianism or Priscillianısm, from a Reichenau MS now at Carlsruhe. Among them No. 49 is headed Incipit diligentia beatorum monachorum Armonii (Armenii m. 2) et Honorii de libris canonicis ueteris atque nous

1 The total of the figures actually given is 5174 ; Titus and Philemon, probably about 150 verses between them, are unrepresented. The result would be close enough to the 5300 of Nicephorus.

2 The simplest change here is to write $5 \mathrm{II}_{4}$ ( $\overline{\mathrm{v}} \mathrm{cmin}$ ) for $11_{4}$, and it is confirmed by the figures for the New Testament as a whole. The sum total of the figures actually given for the different epistles $1 \mathrm{~s} 4714$, but three epistles are unrepresented.

${ }^{3}$ To arrive at the total of 20320 , after deducting 9400 for the Gospels, 2800 for Acts, and 1320 for the Catholic Epistles, we get 6900 left for Epp. Paul and Apoc. To the former should probably be allotted 5150 ( $\overrightarrow{\mathrm{v}} \mathrm{Cr}$ for $\overline{\mathrm{v}} \mathrm{Cl}$ ), to the latter $175^{\circ}$ (i DCCL for I DCCCL).

- I should propose to read $199^{24}$, which would correctly represent the total of Gospels (9370), Acts (2800), Catholıc Epistles (1240), Pauline Epistles (5114), and Apocalypse $(14 \infty)$, and added to the $7990^{4}$ given for $0 . T$. would produce the combined total actually given, 99828 .

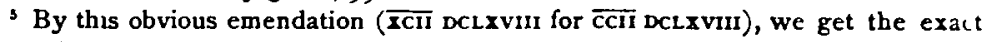
sum of the figures for the two Testaments, $7234^{8}$ and 20320 . 
testamenti sed etiam confessio fidei catholicae quam breuiter wiro inlustr Theofilo direxerunt. Unfortunately the list of canonical books has disappeared and only the profession of faith remains.

This very profession contains, however, one of the only two certain points of literary contact which I have succeeded in establishing with the formula of the Freisingen document : with lines 39-4I of my text compare the following from the creed of the two monks (Kunstle, p. 1 79) 'qualiter autem secreto illo et inenarrabili consilio sit genitus, nullus catholicus prorsus debet hoc proloqui, neque mente uel qualibet cogitatione concipere, cum propheta apertissime increpans dixerit : Generationem autem eius quis enarrabit?' The second parallel is from a document which, though I first noticed it in Quesnel's collection of canons where it is numbered XL and entitled Libellus Augustini de fide catholica contra omnes hereses, occurs also in Künstle's series as No. 5 Regula fidei catholicae concilii Toletanae ciuitatis; Kunstle and Kattenbusch, following Dom Morin, have identified it with a 'libellum in modum symboli' which Gennadius (de uiris illustribus $\$ 76$ ) speaks of as the work of a certain Spanish bishop, Pastor of Palencia. With lines 36-38 of my text compare the following from the Libellus: 'spiritum quoque paracletum esse qui nec pater sit ipse nec filius ... est ergo ingenitus pater, genitus filius, non genitus paracletus sed a patre [filioque ${ }^{1}$ ] procedens.'

These parallels are hardly extensive enough to settle on which side lies the literary obligation; though of the first passage the Freisingen MS certainly preserves a simpler and therefore probably earlier form of words. But we are still thrown back in the main on internal evidence for indications of date; and here, though it is quite true, as Kunstle reminds us, that the controversy with Arianism was a burning one in the West till the end of the sixth century, I should be disposed to look on the employment in the Freisingen document of the original watchwords of Arianism ' erat quando non erat' (1. 10), 'antequam crearetur non erat' (1. 16$)$, as indicative of the earlier period of the struggle, circa $350-430$ A. D. Some support appears also to be lent to this view by the phenomena of the biblical quotations, which are independent of the Vulgate : Jo. xvi 28 is quoted (1. $\left.4^{8}\right)$ in an Old Latin form approaching that of Codex Vercellensis; Matt. xvii 5 (1. 49) is found exactly in this form only in Gaudentius of Brescia and St. Jerome: 'discubitos' in Matt. xxini $6(1.62)$ is again Old Latin.

On the whole, while carefully abstaining from any desire to dogmatize, I incline to the belief that the Latin canon and creed of the Freisingen MS date from about the year 400 A. D., and that the author

1 Filiogue stands in Kanstle's MS, but not in the Quesnel collection. 
depended at least for the stichometry of his biblical list on a Greek original, which may have been as much as fifty or a hundred years older and had perhaps first seen the light at Caesarea. But I shall gratefully welcome any suggestions or criticisms which may help to carry the enquiry further.

C. H. TURner. 